\title{
TINGKAT KESUBURAN PERAIRAN DI WADUK WONOREJO DALAM KAITANNYA DENGAN POTENSI IKAN
}

\author{
Setya W.A. Permanasari ${ }^{a, *}$, Kusriani $^{\mathrm{a}}$, dan Putut Widjanarko ${ }^{\mathrm{a}}$ \\ ${ }^{a}$ Program Studi Manajemen Sumberdaya Perairan, Fakultas Perikanan Dan Ilmu Kelautan, \\ Universitas Brawijaya, Malang, Indonesia \\ "Corresponding author: setya_widhi3@yahoo.com
}

\begin{abstract}
Abstrak
Waduk Wonorejo mendapatkan masukan air secara terus menerus dari Kali Wangi dengan membawa beban limbah dari aktivitas manusia, pertanian, pemukiman dan peternakan. Sehingga dapat memicu kesuburan perairan pada waduk. Kesuburan perairan dapat digambarkan dari nilai Produktivitas Primer yang selanjutnya berguna untuk mengestimasi produksi ikan yang berada di perairan tersebut. Maka dari itu, perlu adanya kajian mengenai tingkat kesuburan perairan di Waduk Wonorejo beserta potensi ikan yang terkandung didalamnya. Digunakan metode observatorial dan metode Tropic State Indeks. Hasil penelitian memiliki kisaran kualitas air yang meliputi suhu: $29-31^{\circ} \mathrm{C}$, kecerahan: $57,5-98,5 \mathrm{~cm}, \mathrm{pH}: 5-7$, DO: $6,21-10,03 \mathrm{mg} / 1, \mathrm{CO}_{2}: 3,9-18,97 \mathrm{mg} / 1$, nitrat: $0,54-1,6 \mathrm{mg} / \mathrm{l}$, dan ortofosfat $0,005-0,168 \mathrm{mg} / 1$, nilai klorofil-a: 2,76 - 16,1 $\mathrm{mg} / \mathrm{m}^{3}$, nilai Produktivitas primer 1,55-4,55 g C/m³ $/ \mathrm{hari}$, dan nilai rataan TSI: 44,368-65,642. Kesimpulan bahwa kesuburan perairan di Waduk Wonorejo tergolong dalam perairan eutrofik ringan sampai dengan eutrofik sedang dan potensi perikanan sebesar 3963,252 ton ikan/tahun. Sehingga diharapkan dapat memberikan gambaran untuk acuan pengelolaan pemerintah setempat dan pengelola dalam mengelola Waduk Wonorejo agar berjalan secara tepat, berkesinambungan serta berkelanjutan.
\end{abstract}

Kata Kunci: Estimasi Potensi Ikan, Eutrofik, Kualitas Air, TSI

\begin{abstract}
Wonorejo Reservoirs gets input water is constantly being from Kali Wangi with carrying burdens waste of human activities, agriculture, settlement and animal husbandry. So, that it can trigger fertility on reservoir waters. Water trophic levels can be described from the primary productivity and useful to estimate production of fish in these waters. Therefore, should have been investigating of water trophic level in Wonorejo Reservoirs and fish potential contained therein. Used method of observatorial and Tropic State Index Method. The result of this research was obtained the range of the quality of water covering the temperature: $29-31{ }^{\circ} \mathrm{C}$, Secchi disk: 57,5 - 98,5 cm, pH: 5 - 7, DO: 6,21 - 10,03 mg/l, $\mathrm{CO}_{2}: 3,9-18,97$ $\mathrm{mg} / \mathrm{l}$, nitrat: $0,54-1,6 \mathrm{mg} / \mathrm{l}$, and ortophospate $0,005-0,168 \mathrm{mg} / \mathrm{l}$, Chlorophyll-a values: $2,76-16,1 \mathrm{mg} / \mathrm{m}^{3}$, Primary Productivity values: $1,55-4,55 \mathrm{~g} \mathrm{C} / \mathrm{m}^{3}$ /days, Avarage TSI values: 44,368-65,642. The conclusion that water trophic level in Wonorejo Reservoirs are classified to light eutrophic up to moderate eutrophic and fisheries potensial as much as 3963,252 ton fish/year. So, is expected to provide a reference to local government management and management Wonorejo Reservoirs in managing to appropriately, continuous and sustainable.
\end{abstract}

Keywords: Estimate of Potensial Fish, Eutrophic, TSI , Water Quality

\section{PENDAHULUAN}

Waduk Wonorejo terletak di desa Wonorejo Kecamatan Pagerwojo Kabupaten Tulungagung. Lokasi bendungan berada pada kali Gondang \pm 400 meter di hilir pertemuan antara Kali Bodeng dengan Kali Wangi. Hulu kali Gondang berada di selatan Gunung
Wilis. Pembangunan waduk bertujuan sebagai pengendalian banjir di kota seluas $1.055,65 \mathrm{~km}^{2}$ [1]. Masukan air Kali Mati menjadi salah satu media bagi masuknya bahan organik maupun anorganik yang berasal dari aktivitas manusia di sekitar waduk maupun sekitar sungai. Beban masukan tersebut dapat memacu tingkat 
kesuburan pada perairan waduk, dan apabila terjadi eutrofikasi secara terus menerus maka dapat mengalami pendangkalan maupun sedimentasi.

Semua perairan waduk akan mengalami eutrofikasi setelah 1-2 tahun inundasi (pengisian air karena sebagai hasil dekomposisi bahan organik). Eutrofikasi akan menyebabkan meningkatnya produksi ikan sebagai kelanjutan dari tropik level organik dalam suatu ekosistem [2], [3].

Tingkat kesuburan perairan dapat diduga dengan nilai produktivitas primer di suatu perairan. Produktivitas primer dapat diukur dengan berbagai cara, salah satunya adalah dengan mengukur klorofil-a [4].

Potensi perikanan merupakan salah satu kekuatan yang dimiliki badan perairan dalam memproduksi sumberdaya perikanan pada satuan waktu tertentu. Estimasi potensi produksi ikan sangat penting dilakukan untuk perlu diketahui guna proses optimasi pemanfaatan dan pengelolaan sumberdaya ikan di suatu badan air agar tetap lestari [5], [6]. Maka dari itu dalam upaya mengelola Waduk Wonorejo secara lestari perlu adanya kajian terlebih dahulu mengenai kondisi perairan di waduk tersebut, bagaimana tingkat kesuburan perairan guna mengestimasi potensi perikanan di waduk tersebut.

\section{BAHAN DAN METODE}

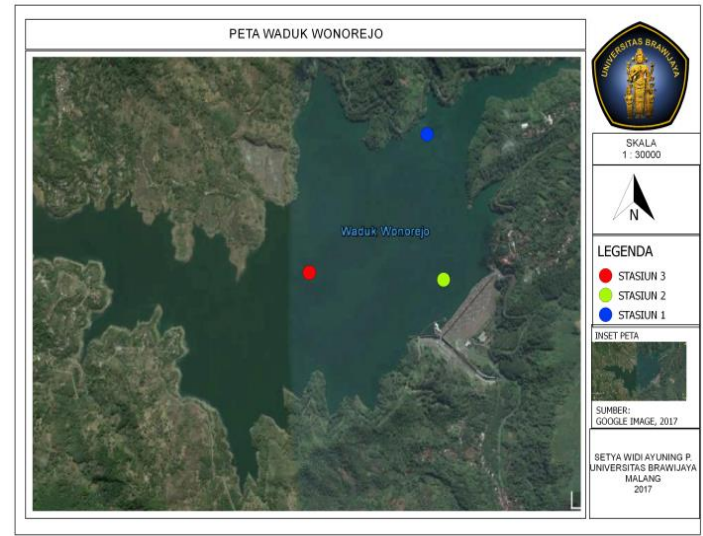

Gambar 1. Peta Waduk Wonorejo

Keterangan :

Statiun $1=111^{\circ} 48^{\prime} 9,52^{\prime \prime}$ BT $8^{\circ} 6^{\prime} 33.37^{\prime \prime}$ LS

Statiun $2=111^{\circ} 48^{\prime} 13,08^{\prime \prime}$ 'BT $8^{\circ} 11^{\prime} 20,11^{\prime \prime}$ LS

Statiun $3=111^{\circ} 47^{\prime} 43,37^{\prime \prime} B T 8^{\circ} 11^{\prime} 5$ ' $5^{\prime \prime}$ LS
Materi yang digunakan dalam penelitian ini adalah klorofil-a dengan parameter pendukung meliputi biologi (struktur komunitas fitoplankton), fisika (suhu, kecerahan) dan kimia (derajat keasaman/pH, oksigen terlarut (DO), karbondioksida bebas $\left(\mathrm{CO}_{2}\right)$, nitrat dan ortofosfat) menggunakan metode APHA, 1995. Pengambilan sampel dilakukan pada 3 stasiun selama 8 minggu mulai Juli-September 2017.

\section{Konsentrasi klorofil-a}

Konsentrasi klorofil-a menggunakan rumus Vollenweider (1969) [7], sebagai berikut :

$$
\text { Chl }-a\left(\mathrm{mg} / \mathrm{m}^{3}\right)=11,9(A 665-A 750) x \frac{\mathrm{V}}{\mathrm{L}} \times \frac{1000}{\mathrm{~s}}
$$

Keterangan :

$11,9=$ konstanta

A665 = absorbansi spektrofotometer $665 \mathrm{~nm}$

A750 = absorbansi spektrofotometer $750 \mathrm{~nm}$

$\mathrm{V}=$ volume ekstrak aceton $(\mathrm{ml})$

$\mathrm{L} \quad=$ lebar diameter cuvet $(1 \mathrm{~cm})$

$\mathrm{S} \quad=$ volume sampel air yang di saring (l)

\section{Analisa data}

\section{1) Status Trofik Perairan}

Tingkat kesuburan perairan dapat diketahui dengan perhitungan Tropic State Index (TSI). Skor status trofik suatu perairan merupakan nilai rataan dari nilai TSI ketiga parameter (Secchi Disk, Klorofil-a, Ortophospat) [8],sebagai berikut :

$$
\begin{aligned}
& T S I(S D)=10\left(6-\frac{\ln S D}{\ln 2}\right) \\
& T S I(C h l)=10\left(6-\frac{2.04-0.68 \ln C h l}{\ln 2}\right) \\
& T S I(T P)=10\left(6-\frac{\ln \frac{48}{T P}}{\ln 2}\right) \\
& \text { Rataan TSI }=\left(\frac{T S I(S D)+T S I(C h l)+T S I(T P)}{3}\right)
\end{aligned}
$$

Keterangan :

TSI = Tropic State Index

$\mathrm{SD} \quad=$ Secchi Disk

Chl = Klorofil-a

$\mathrm{TP}=$ Ortophospat 
Berdasarkan hasil TSI yang diperoleh pada penelitian tersebut maka tingkat kesuburan perairan dapat digolongkan menurut Carlson (1977) menjadi : oligotrofik (40), Mesotrofik (40-50), eutrofik (50-70), Hipereutrofik (70-80), Hipereutrofik dengan algae scum atau blooming algae (80) [9].

\section{2) Produktivitas Primer}

Nilai klorofil yang didapatkan dapat ditransformasikan ke dalam bentuk produktivitas primer menggunakan rumus[10]:

$$
P P=56,5 x(\text { Klorofil }-a)^{0,61}
$$

\section{3) Pendugaan Potensi Ikan dengan Pendekatan Produktivitas Primer}

Potensi ikan dapat diketahui dengan melakukan konversi dari nilai produktivitas primer menjadi berat basah ikan yang dihasilkan per tahun. Produksi ikan diestimasikan sebesar 1-3\% dari produktivitas primer. Nilai produktivitas primer $(\mathrm{g}$ $\mathrm{C} / \mathrm{m}^{2} /$ tahun) dikonversi menjadi g Cikan $/ \mathrm{m}^{2} /$ tahun dengan mengalikan nilai produktivitas primer dengan persentase konversi [11].

\section{HASIL DAN PEMBAHASAN}

\section{Hasil kualitas air}

Pengukuran kualitas air di tiga stasiun pada Waduk Wonorejo didapatkan, seperti tersaji pada Tabel 1.

Nilai suhu di Waduk Wonorejo selama penelitian relatif stabil berkisar $29-31{ }^{\circ} \mathrm{C}$.
Suhu optimum untuk kehidupan plankton 25$30^{\circ} \mathrm{C}$, kisaran pada suhu $10-35{ }^{\circ} \mathrm{C}$ dapat meningkatkan laju fotosintesis, dan untuk kegiatan perikanan budidaya berkisar antara 25 - $32{ }^{\circ} \mathrm{C}$ [12]-[14]. Berdasarkan nilai kecerahan yang diperoleh pada tiga stasiun di Waduk Wonorejo yaitu berkisar 57 - 98,5 $\mathrm{cm}$. Kecerahan tersebut dipengaruhi oleh kekeruhan pada perairan dimana kekeruhan ini berasal dari partikel-partikel tersuspensi. Transparansi cahaya yang optimal untuk kehidupan plankton yaitu berkisar $30-10 \mathrm{~cm}$ [12].

Nilai pH pada Waduk Wonorejo relatif stabil tiap minggunya yaitu berkisar $5-7$. Nilai $\mathrm{pH}$ yang mendukung untuk pertumbuhan dan perkembangbiakan organisme akuatik berkisar antara $6-9$ [12], [15], [16]. Berdasarkan hasil pengukuran DO pada Waduk Wonorejo ini berkisar $6,21-10,03 \mathrm{mg} / \mathrm{l}$. Tinggi rendahnya DO pada waduk dipengaruhi oleh hasil aktivitas fotosintesis fitoplankton, dimana kelimpahan fitoplankton pada Waduk Wonorejo cukup tinggi. Selain itu tinggi rendahnya DO pada perairan juga dipengaruhi oleh difusi oksigen dari udara. Kandungan oksigen terlarut optim um untuk kehidupan organisme akuatik yaitu 5-7 mg/l [17]. Kisaran $\mathrm{CO}_{2}$ pada Waduk Wo norejo yaitu 3,9 mg/l-19,97 mg/l. Kandungan $\mathrm{CO}_{2}$ yang mendukung populasi ikan yang baik normalnya mengandung kurang dari $5 \mathrm{mg} / \mathrm{l}$ karbondioksida bebas [18].

Nilai nitrat pada waduk wonorejo ini berkisar $0,544 \mathrm{mg} / \mathrm{l}-1,71 \mathrm{mg} / \mathrm{l}$. Menurut Leenvart (1980) dalam [19], Perairan oligotrophik mempunyai

Tabel 1. Hasil Kualitas Air pada Waduk Wonorejo

\begin{tabular}{cllll}
\hline No & Parameter & ST 1 & ST 2 & ST 3 \\
\hline 1. & Suhu $\left({ }^{\circ} \mathrm{C}\right)$ & $29-31$ & $29-31$ & $29-31$ \\
\hline 2. & Kecerahan $(\mathrm{cm})$ & $57,5-85$ & $60-92,5$ & $60-98,5$ \\
\hline 3. & $\mathrm{Ph}$ & 7 & $6-7$ & $5-7$ \\
\hline 4. & $\mathrm{DO}(\mathrm{mg} / \mathrm{l})$ & $6,21-9,90$ & $6,35-8,24$ & $6,28-10,03$ \\
\hline 5. & $\mathrm{CO}_{2}(\mathrm{mg} / \mathrm{l})$ & $3,98-12,35$ & $4,25-16,10$ & $4,10-19,97$ \\
\hline 6. & Nitrat $(\mathrm{mg} / \mathrm{l})$ & $0,54-1,48$ & $0,88-1,71$ & $0,84-1,44$ \\
\hline 7. & Ortofosfat $(\mathrm{mg} / \mathrm{l})$ & $0,012-0,044$ & $0,004-0,168$ & $0,008-0,142$ \\
\hline
\end{tabular}


kandungan nitrat kurang dari $0,10 \mathrm{mg} / \mathrm{l}$, mesotrophik $\quad 0,10-0,15 \quad \mathrm{mg} / 1$ sedangkan eutrophik lebih besar dari $0,2 \mathrm{mg} / \mathrm{l}$. Kisaran Nilai orthofosfat pada Waduk Wonorejo didapatkan 0,004-0,168 mg/l. Berdasarkan kisaran rata-rata tersebut Waduk Wonorejo masih dapat dikatakan pada kondisi baik seperti yang dijelaskan oleh [20], suatu perairan relatif subur jika kandungan fosfatnya berada pada kisaran $0,06 \mathrm{mg} / \mathrm{l}-10$ $\mathrm{mg} / \mathrm{l}$. Sehingga Waduk Wonorejo ini dapat dikategorikan sebagai perairan eutrofik.

\section{Produktivitas Primer}

Pengukuran produktivitas primer dapat dilakukan secara kuantitas dan kualitas, kuantitas dapat diukur dengan menggunakan metode klorofil-a dan kepadatan plankton. Sedangkan kualitas dapat diketahui dengan menentukan index diversitas (ID).

\section{Klorofil-a}

Hasil pengukuran klorofil-a pada waduk Wonorejo ini nilai tertinggi terdapat pada stasiun satu minggu ke 4 yaitu $16,1 \mathrm{mg} / \mathrm{m}^{3}$. Sedangkan untuk nilai terendah terdapat pada stasiun dua minggu ke 2 yaitu $2,76 \mathrm{mg} / \mathrm{m}^{3}$. Hal ini diakibatkan kandungan kandungan nutrien di stasiun 2 relatif rendah baik nitrat maupun ortofosfatnya. Nutrien pada perairan merupakan faktor penting dalam proses pertumbuhan dan reproduksi fitoplankton [21]. Menurut Novotny \& Olem (1994), perairan oligotrofik bila kandungan klorofil $<4 \mathrm{mg} / \mathrm{m}^{3}$, mesotrofik bila kandungan klorofil antara $4-10 \mathrm{mg} / \mathrm{m}^{3}$ dan eutrofik bila kandungan klorofil $>10 \mathrm{mg} / \mathrm{m}^{3}$ [22]. Nilai klorofil-a di Waduk Wonorejo mencapai $16,1 \mathrm{mg} / \mathrm{m}^{3}$, sehingga dapat digolongkan perairan mesoeutrofik sampai dengan eutrofik.

\section{Kelimpahan Fitoplankton}

Dalam ekosistem akuatik, sebagian besar yang melakukan produktivitas primer oleh fitoplankton [23]. Hasil kelimpahan fitoplankton pada Waduk Wonorejo dapat dilihat pada Gambar 2.

Kelimpahan fitoplankton yang ditemukan pada Waduk Wonorejo berkisar antara 19500$159750 \mathrm{sel} / \mathrm{ml}$, dengan kelimpahan tersebut maka Waduk Wonorejo termasuk dalam perairan eutrofik. Sesuai dengan pernyataan [19], menyatakan bahwa perairan dengan kelimpahan fitoplankton $15000 \mathrm{sel} / \mathrm{ml}$ tergolong dalam perairan eutrofik.

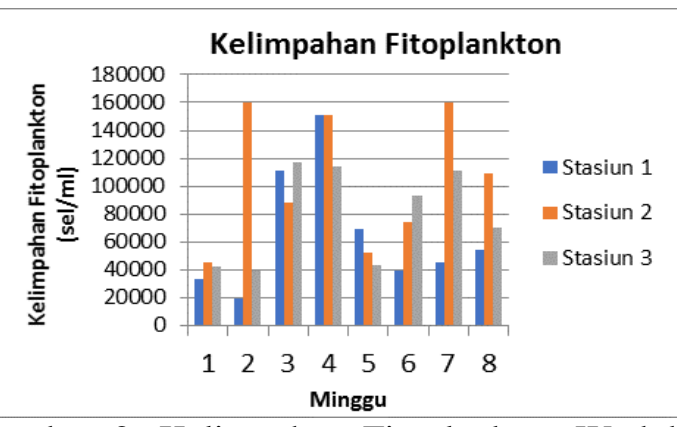

Gambar 2. Kelimpahan Fitoplankton Waduk Wonorejo

\section{Indeks Diversitas}

Indeks diversitas di Waduk Wonorejo rata-rata tiap minggunya $\mathrm{H}^{\prime}$ berkisar antara 1,87 - 2. keanekaragaman rendah bila $0<\mathrm{H}^{\prime}$ $<2,30$, keanekaragaman sedang bila 2,302 < $\mathrm{H}^{\prime}<6,907$ keanekaragaman tinggi bila $\mathrm{H}^{\prime}>$ 6,907 [23]. Berdasarkan kriteria tersebut dapat disimpulkan bahwa Waduk Wonorejo ini mempunyai tingkat keanekaragaman plankton yang rendah. Tingkat keanekaragaman yang rendah ini terjadi akibat adanya dominasi spesies tertentu pada perairan. Filum atau jenis yang mendominasi biasanya dipengaruhi oleh kandungan unsur hara terutama $\mathrm{N}$ dan $\mathrm{P}$ yang berada pada Waduk. Tinggi rendahnya kandungan fosfat dalam perairan merupakan pendorong terjadinya dominasi fitoplankton tertentu, yaitu perairan dengan kandungan fosfat rendah $(0,00-0,02 \mathrm{mg} / \mathrm{l})$ akan didominasi oleh Diatom, pada kadar sedang (0,02-0,05 mg/l) didominasi oleh Chlorophyta dan pada kadar tinggi (lebih dari $0,10 \mathrm{mg} / \mathrm{l}$ ) didominasi oleh jenis Cyanophyta [24], [25].

\section{Produktivitas Perairan}


Hasil perhitungan produktivitas primer berdasarkan nilai klorofil-a di Waduk Wonorejo disajikan pada Tabel 3. Hasil perhitungan PP pada tabel 3 didapatkan 1,63$4,55 \mathrm{~g} \mathrm{C}^{3} /$ hari.

Produktivitas primer dalam perairan memiliki hubungan yang erat dengan kelimpahan fitoplankton, apabila produktivitas primer di perairan tinggi maka kelimpahan alga di perairan tinggi pula [26]. Namun hasil PP yang didapatkan antara produktivitas primer dengan kelimpahan fitoplankton tidak berbanding lurus. Hal ini dikarenakan nilai klorofil-a yang didapat pada stasiun 2 rendah dibanding stasiun yang lainnya. Hal ini diakibatkan karena perbedaan kuantitas klorofil-a pada setiap jenis fitoplankton. Kandungan klorofil-a pada suatu perairan belum tentu memiliki hubungan keeratan yang kuat dengan kelimpahan fitoplankton. Hal ini dikarenakan beberapa faktor diantaranya kondisi proporsi klorofil-a yang berbeda pada setiap jenis fitoplankton dan adanya sel fitoplankton yang berukuran kecil sehingga tidak tertangkap dengan jaring plankton sehingga tidak semua sel fitoplankton terkuantifikasi [21].

Tabel 3. Hasil Perhitungan Produktivitas Primer $\left(\mathrm{g} \mathrm{C} / \mathrm{m}^{3} /\right.$ hari $)$

\begin{tabular}{|c|c|c|c|c|}
\hline \multirow{2}{*}{ Minggu } & \multicolumn{3}{|c|}{ Stasiun } & \multirow{2}{*}{$\begin{array}{l}\text { Rata- } \\
\text { Rata }\end{array}$} \\
\hline & 1 & 2 & 3 & \\
\hline 1 & 2,24 & 1,67 & 2,28 & 2,06 \\
\hline 2 & 1,72 & 1,55 & 2,06 & 1,78 \\
\hline 3 & 2,16 & 1,63 & 2,16 & 1,99 \\
\hline 4 & 4,55 & 3,32 & 3,11 & 3,66 \\
\hline 5 & 2,32 & 2,27 & 1,65 & 2,08 \\
\hline 6 & 3,14 & 3,31 & 3,25 & 3,24 \\
\hline 7 & 2,18 & 2,18 & 2,12 & 2,16 \\
\hline 8 & 1,81 & 2,14 & 2,95 & 2,30 \\
\hline
\end{tabular}

\section{Tropic State Index (TSI)}

TSI merupakan suatu metode sederhana yang dapat digunakan untuk menentukan suatu kesuburan perairan dengan menggunakan tiga parameter yang saling berkaitan yaitu kecerahan, fosfat dan klorofila [9]. Hasil analisis ketiga parameter dengan menggunakan rumus TSI disajikan pada Tabel 2.

Secara umum, berdasarkan nilai TSI yang diperoleh maka perairan Waduk Wonorejo termasuk dalam perairan eutrofik ringan menuju eutrofik sedang dengan kisaran nilai TSI yaitu 44,368-65,642. Kondisi perairan ini perlu di waspadai karena dengan berjalannya waktu waduk akan terus terjadi penurunan kecerahan air, terjadi dominasi alga jenis cyanophyta dan dapat menimbulkan masalah pada zona hipolimnetik bersifat anoksik. Tingkat kesuburan perairan yang terlalu subur dapat menurunkan produksi perikanan serta menimbulkan gulma air yang sangat cepat, apabila tidak ditangani lebih awal [6], [8].

Tabel 2. Nilai TSI klorofil-a, kecerahan, ortofosfat di Waduk Wonorejo

\begin{tabular}{ccccc}
\hline $\begin{array}{c}\text { Stas- } \\
\text { iun }\end{array}$ & $\begin{array}{c}\text { TSI } \\
\text { Chl }\end{array}$ & TSI SD & TSI TP & $\begin{array}{c}\text { Rataan } \\
\text { TSI }\end{array}$ \\
\hline 1 & 47,517 & 64,8347 & 49,0188 & 53,790 \\
\hline 2 & 45,919 & 64,4779 & 52,0300 & 54,142 \\
\hline 3 & 47,458 & 64,2552 & 64,0788 & 58,597 \\
\hline $\begin{array}{c}\text { Rata- } \\
\text { Rata }\end{array}$ & 46,965 & 64,5226 & 55,0425 & 55,510 \\
\hline
\end{tabular}

\section{Pendugaan Potensi Ikan dengan Pendekatan Produktivitas Primer}

Daya dukung perairan Waduk dapat diketahui dengan menggunakan analisis produktivitas primer di perairan tersebut. Kemampuan perairan dalam memproduksi ikan atau untuk mengetahui potensi waduk tersebut melalui konversi dalam tabel Beveridge. Hasil pendugaan potensi ikan ini tersajikan pada Tabel 4.

Berdasarkan hasil perhitungan diketahui rata-rata kemampuan waduk dalam memproduksi ikan sebesar 3963,252 ton ikan/tahun. Potensi perikanan ini merupakan suatu kekeuatan yang dimiliki oleh perairan dalam memproduksi sumberdaya perikanan pada satuan waktu tertentu. Potensi perikanan ini merupakan potensi sumberdaya alam yang dapat diperbarui atau pulih. Namun kegiatan perikanan baik untuk penangkapan maupun budidaa juga harus tetap mempertahankan - 
Tabel 4. Hasil Perhitungan Pendugaan Potensi Ikan

\begin{tabular}{crcc}
\hline $\begin{array}{c}\text { Potensi Waduk (ton } \\
\text { ikan/3850000 m2/365 hari) } \\
\text { per minggu }\end{array}$ & \multicolumn{3}{c}{ Stasiun } \\
\cline { 2 - 4 } & 1 & 2 & 3 \\
\hline 2 & 3464,793 & 2341,708 & 3531,480 \\
3 & 2414,709 & 2181,507 & 3189,340 \\
4 & 3346,070 & 2295,335 & 3341,780 \\
5 & 10827,944 & 5605,678 & 5239,870 \\
6 & 3580,971 & 3834,419 & 2313,955 \\
7 & 5689,993 & 5591,317 & 5490,243 \\
8 & 3363,194 & 3363,194 & 3277,004 \\
\multicolumn{4}{c}{ RATA-RATA } \\
\hline
\end{tabular}

tingkat produksinya, terutama di perairan Waduk [5]. Estimasi potensi produksi sangatlah penting untuk dilakukan. Hal ini bertujuan untuk dapat mengoptimasi pemanfaatan dan pengelolaan sumberdaya ikan di suatu perairan agar tetap lestari dan berkelanjutan [6].

\section{KESIMPULAN}

Berdasarkan penelitian yang dilakukan di Waduk Wonorejo Kabupaten Tulungagung dapat diambil kesimpulan bahwa :

- Tingkat kesuburan perairan Waduk Wonorejo berdasarkan indeks status trofik termasuk ke dalam perairan eutrofik ringan sampai dengan perairan eutrofik sedang.

- Nilai estimasi pendugaan produksi ikan di Waduk Wonorejo, dengan pendekatan produktivitas primer adalah sebesar 3963,252 ton ikan/tahun.

\section{UCAPAN TERIMAKASIH}

Terimakasih atas bantuan penelitian dari Fakultas Perikanan dan Ilmu Kelautan Universitas Brawijaya.

\section{DAFTAR PUSTAKA}

[1] Perusahaan Umum (PERUM) Jasa Tirta I, "Echo Sounding (Pengukuran Penampang Melintang Waduk) Wonorejo," Tidak Dipublikasikan.
Malang: Perusahaan Umum (PERUM) Jasa Tirta I, 2004.

[2] D. G. R. Wiadnya, L. Sutini, dan T. F. Lelono , "Manajemen Sumberdaya Perairan Dengan Kasus Perikanan Tangkap di Jawa Timur," Fakultas Perikanan Universitas Brawijaya. Malang, 1993.

[3] E. Apridayanti, "Evaluasi Pengelolaan Lingkungan Perairan Waduk Lahor Kabupaten Malang Jawa Timur," Universitas Diponegoro Semarang, 2008.

[4] T. Z. U Prianto dan R. Aryawati, "Pola Sebaran Konsentrasi Klorofil-a di Selat Bangka dengan Menggunakan Citra Aqua-Modis," Maspari Journal., vol. 5 (1), pp. 22-23, 2013.

[5] R. Dahuri, "Pengelolaan Sumberdaya Wilayah Pesisir dan Lautan Secara Terpadu," Jakarta. Pt. Pradnya Paramita. 465-485, Aug. 2007.

[6] Purnomo, W. Andri, dan S. K. Endi, "Daya Dukung dan Potensi Ikan Waduk Sempor Di Kebumen Provinsi Jawa Tengah," Jurnal Lit Perikanan Ind., vol 19, No. 4, pp 203-212. 2013

[7] C. E. Boyd, "Water Quality in Warm Water Fish Pond," Autum University, Alabama, 1979. 
[8] R. E. Carlson "A Tropic State Indeks For Lakes," Limnology and Oceanography, 1977.

[9] F. R. Shaleh, K. Soewardi, dan S. Hariyadi, "Kualitas Air Status Kesuburan Perairan Waduk Sempor, Kebumen," Jurnal Ilmu Pertanian Indonesia (JIPI), Vol 19 (3), pp 169-173.

[10] M. C. M. Beveridge, "Cage and Pen Fish Farming: Carring Capacity Models and Environmental Impact," FAO Fish Tech. Pap (225) 131 p, 1984.

[11] M. Mahmudi, "Estimasi Produksi Ikan Melalui Nutrien Seresah Daun Mangrove di Reboisasi Rhizophora, Nguling, Pasuruan, Jawa Timur," Ilmu Kelautan, Vol 15 (4), pp 231-235. 2010.

[12] C. E. Boyd, "Water Quality in Ponds For Aquaculture," Albama Agricultural. Experient Stasion. Alabama. Pp 482, 1990.

[13] C. S. Reynolds, "Ecology of Freshwater Phytoplankton," Cambridge University Press. Cambridge pp 383

[14] S. M. Haslam, "River Pollution and Ecological Perspective," John Willey and Sons, Chichester, UK, pp 253, 1995.

[15] Peraturan Pemerintah Republik Indonesia. "Pengelolaan Kualitas Air dan Pengendalian Pencemaran Air," Peraturan Pemerintah Republik Indonesia Nomor 82, 2001.

[16] V. Novotny dan H. Olem, "Water Quality, Prevention Identification and Management of Diffuse Pollution," Van Nostrans Reinhold. New York. Vol 19, pp 464-468, 1994.
[17] M.G.H. Kordi, dan A.B. Tancung, "Pengelolaan Kualitas Air Dalam Budidaya Perairan," Rineka Cipta. Jakarta, 2007.

[18] C. E. Boyd, "Water Quality Management For Pond Fish Culture," Autum University. Alabama

[19] H. U. Subarijanti, "Pemupukan dan Kesuburan Perairan," Fakultas Perikanan Universitas Brawijaya. Malang, 2000.

[20] C.R Goldman dan A.J Horne, "Limnology," Mc. GrawHill Book Company. New York. pp 464, 1983.

[21] R. Aryawati dan H. Thoha, "Hubungan Kandungan Klorofil-a dan Kelimpahan Fitoplankton di Perairan Berau Kalimantan Timur," Maspari Journal, vol 2, pp 89-94, 2011.

[22] H. Effendie, "Telaah Kualitas Air Bagi Pengelolaan Sumberdaya dan Lingkungan Perairan," Kanisius. Yogyakarta. 2003

[23] R. G. Wetzel, "Limnology," Lake and River Ecosystem. Ed $3^{\text {th }}$. Academic Press. New York. London

[24] M. H. Siregar, "Studi Keanekaragaman Plankton di Hulu Sungai Asahan Porsea," USU. Medan, 2010.

[25] W. K. Liaw, "Chemical and Biological Studies of Fish Ponds and Reservoirs in Taiwan," Reprinted From Chinese America Joint Commision on Rural. Series (7). Pp 1-43, 1969.

[26] S. S. Hariyadi, dan B. Widigdo, "Limnologi Metode Kualitas Air," Institut Pertanian Bogor. 2010. 